King, G. (2014). The power of the treacherous interpreter: Multilingualism in Jacques Audiard's Un prophète. Linguistica Antverpiensia, New Series. Themes in Translation Studies, 13, 78-92.

\title{
The power of the treacherous interpreter: Multilingualism in Jacques Audiard's Un prophète
}

\section{Gemma King}

The University of Melbourne \& Université Paris 3: Sorbonne Nouvelle, Australia \& France gemma.king@unimelb.edu.au

Representations of multilingualism as power are steadily increasing in prevalence in the French cinema of the twenty-first century. In contemporary multilingual French cinema, language functions not only as a vessel of meaning, but as a socially loaded and complex tool which is far from neutral. In films such as Welcome (Lioret, 2009), Polisse (Mä̈wenn, 2011), London River (Bouchareb, 2010) and De battre mon coeur s'est arrêté (Audiard, 2005), characters often exploit their multilingualism in order to exercise authority. Consequently, language can constitute a narrative device in itself, and a weapon to be harnessed and deployed in the pursuit of power. This article examines Jacques Audiard's Un Prophète (2009), a film which contains dialogue in languages other than French and whose characters consistently employ code switching as a strategy for exerting dominance over one another. Significantly, the protagonist Malik's multilingual power play comes to a head in his adoption of the role of what we shall label the treacherous interpreter, exploiting the measure of trust ritually assigned to the translator in order to manipulate his adversaries and wrest himself a unique position of power. The film thus calls into question not only the shifting status of marginalised languages in French society, but also the delicate and crucial role of translation in a social landscape marked by linguistic hybridity and intercultural conflict.

\section{Introduction}

In a society increasingly characterised by multiculturalism and linguistic diversity, a significant number of contemporary French films are exploring and foregrounding the role of multilingualism. In contemporary French multilingual film, language functions not only as a vessel of meaning, but also as a socially loaded and complex tool. Characters actively exploit their multilingualism in order to exert symbolic power: they may switch to a language other characters cannot understand in order to conspire, exclude or intimidate, or flaunt their linguistic competence in order to gain access to, or acceptance by, a particular cultural group. Abecassis (2010) has remarked that "Francophone cinema is a plural, indeed multi-ethnic cinema" (p. 35) and multilingual film reflects the 
complex linguistic web of this cultural reality. Yet multilingual dialogue is not merely included in these films as a means of representing the reality of multicultural interaction, and language choice is rarely arbitrary. Instead, multilingualism constitutes a central thematic concern and, frequently, a narrative device: as O'Sullivan (2008) explains, "subtitled foreign dialogue is no longer used merely as ornament, to mark location or nationality, but becomes a vehicle for plot and character development" (p. 84). In this way, contemporary French multilingual film is a cinematic phenomenon which places the power dynamics of multilingualism at its very core.

Through an analysis of Jacques Audiard's 2009 film Un prophète, this article focuses on the place of translation in multilingual cinema. In particular, it explores a specific interpreting phenomenon, whereby the interpreter exploits his/her authority, providing a false translation as a means of manipulating others. Through close examination of an interpreting sequence from $U n$ prophète, the article explores the interpreter's capacity to twist the content being translated for his/her own benefit. We will call this practise that of the treacherous interpreter.

\section{The interpreter in contemporary French multilingual film}

Given that multilingual cinema is concerned with linguistic plurality on both a narrative and thematic level, it is perhaps unsurprising that representations of the figure of the interpreter, and of diegetic interpreting sequences, appear in a number of contemporary French multilingual films (such as Cantet's Entre les murs [2008], Ismaël Ferroukhi's Le Grand Voyage [2004] and Tony Gatlif's Exils [2004]). Interpreting provides the ideal scenario for exploring language politics, and for placing multilingualism at the forefront of a film's focus; as Dwyer (2005) states, "polyglot films celebrate the multiplicity of language by making (mis)translation central to the film's rationale" (p. 305). In such films, the interpreter is consistently represented as a figure equipped with the potential for wielding power. The interpreter as a powerful figure is a familiar concept: Delabastita (2005), for one, emphasises the "translator's central position and thus...the enormous power and responsibility they have in multilingual communication" (p. 19).

It appears necessary at this point to provide a definition of "multilingual film". On the most basic level, the term refers to films including dialogue composed of two or more languages. However, it would be excessive to label a film which includes a smattering of words or phrases in a foreign language a multilingual film. Wahl (2005) pinpoints this dilemma in his article "Discovering a Genre: The Polyglot Film" by labelling minor or superficial instances of multilingualism in cinema as "postcarding" (p. 2), as distinct from the meaningful engagement with language observable in "polyglot" cinema. "Wahl's article is a key work in delineating multilingual film as a cinematic phenomenon, and a number of scholars have followed his lead in foregrounding issues of multilingualism in contemporary cinema (Dwyer, 2005; Gramling, 2010; Smith, 2010, 2012). 
Of course, multilingualism is not a trait confined to French cinema alone, as such non-French multilingual films as Babel (Iñárritu González, 2006), Inglourious Basterds (Tarantino, 2009) and Lost in Translation (Coppola, 2004) attest. Nonetheless, while multilingual film certainly exists beyond the French context, it is particularly salient in French cinema. Not only does France produce more multilingual films per year than other countries (with 65 multilingual releases in 2009 alone, Un prophète's year of release), ${ }^{2}$ but French films remain the most frequently studied multilingual films in cinema scholarship. Indeed, a number of French filmmakers, including Carion (Joyeux Noël, 2005, L'Affaire Farewell, 2009) and Lioret (Welcome, 2009) have stated the extent to which multilingualism is central to their films, Carion even going so far as to suggest that he would have refused to make his First World War tale Joyeux Noël in the French language alone, despite not being particularly fluent in other languages himself (Carion, 2005).

Cinematic representations of the ritual of interpreting abound in French cinema. In numerous multilingual films, including Welcome, Polisse (Maïwenn, 2011), London River (Bouchareb, 2009) and L'Affaire Farewell, interpreters function as pivotal characters. These interpreters vary in their levels of professionalism, from qualified, official employees in L'Affaire Farewell (in which both the French and American presidents - overt holders of positions of power - are at the mercy of an interpreter) to amateur, unofficial exchanges, such as in Welcome, in which the trilingual Kurdish immigrant Bilal casually translates between his monolingual Kurdish-speaking friend, Zoran, and his French acquaintance, Simon, using Kurdish and Bilal and Simon's only shared language, English. The conditions of L'Affaire Farewell and Welcome's contrasting interpreting scenarios are clearly disparate, and there is no suggestion in Welcome that Bilal has undertaken any kind of official interpreting training; indeed, his age, seventeen, suggests this is almost certainly not the case. Yet the interpreting subjects in each of these films enter into the interpreting ritual with trust and ease, and the interpreter's words are accepted by both sides without suspicion.

A striking example of the power of the interpreter can be observed in Cantet's 2008 film, Entre les murs. Situated entirely within the environment of a high school in the multicultural twentieth arrondissement of Paris, the film explores the tensions between a bourgeois French teacher and his diverse and rebellious group of students. In its portrayal of cultural conflict playing out in a French public institution, Entre les murs clearly shares several characteristics with Un prophète, and language takes on a similarly central role. In Cantet's film, following a display of violence in the classroom, an adolescent Malian student, Souleymane, is summoned to a disciplinary hearing with his mother, in order to determine whether or not he will be expelled. Partway through the hearing, as one of the teachers addresses Souleymane's mother, it becomes apparent that the latter does not speak or understand French. As the only person in the room proficient in both French and his mother's native Berber tongue, Souleymane is called upon to interpret for his mother, and therefore to facilitate the hearing which will ultimately 
lead to his expulsion. Indeed, without Souleymane's translation, the committee meeting cannot continue.

In the early stages of the meeting, Souleymane whispers in Berber to his mother, translating the French-language conversation for her benefit (although she initially claims she understands). However, when Souleymane's mother begins to respond heatedly to him in Berber, the committee members step in.

Principal [French]: Excuse me...

[Mother continues to speak to Souleymane in Berber in a raised voice.]

Mother [French]: Messieurs, Mesdames [switches to Berber, dialogue].

[Silence.]

Teacher [to Souleymane, French]: Can you translate?

[Pause.]

Souleymane [French]: She says I'm a good boy.

Mother: [Berber dialogue].

Souleymane [French]: I do my homework. I help my brothers and sisters with their work when I can.

Mother: [Berber dialogue.]

Souleymane [French]: I always wash the dishes and help her when I can.

[Silence.]

Throughout this scene, Souleymane's mother's dialogue remains unsubtitled. As a result, the viewer is placed in the same position of trust as the committee members, and Souleymane maintains a unique position of linguistic authority both over the film's characters and its audience (provided the latter does not understand both Berber and French). This technique is also used in Godard's 1962 film Le Mépris, in which the English, French, Italian and German dialogue is diegetically translated through the device of a quadrilingual interpreter.

Indeed, despite the prominence of languages other than French in contemporary French cinema, multilingualism has also been present in cinema prior to the twenty-first century. In fact, there are numerous cases of multilingualism in French cinema from earlier periods, an obvious example being Renoir's 1937 First World War tale La Grande Illusion, in which almost equal parts of German, English and French, with a smattering of Russian, are spoken. Another important multilingual film is the aforementioned quadrilingual Le Mépris (Dwyer, 2005, p. 298). ${ }^{3}$ Similarly, the cinéma de banlieue and cinéma beur movements of the late twentieth century often feature (albeit brief) excerpts of typically migrant languages such as Arabic. These movements were followed by a number of pioneering multilingual films in the early years of the twenty-first century, notably Haneke's Code inconnu: récits incomplets de divers voyages (2001), comprised of a mix of Arabic, English, French, French Sign Language, German, Malinka and Romanian. This is not to neglect Klapisch's extremely successful L'Auberge Espagnole (2002), whose 
Western European twenty-something characters speak in a confusion of Castilian Spanish, Catalan, Danish, English, French, German and Italian. ${ }^{4}$

The prominence of co-productions (from periods as diverse as the 1930s [with films such as La Grande Illusion and the Franco-German Allo Berlin? Ici Paris! (Duvivier, 1932)] to the contemporary era, with super-co-productions like the 2005 French, German, British, Belgian, Romanian and Norwegian-funded Joyeux Noël [Christian Carion]) is also worth acknowledging in any study on multilingualism in French cinema. Indeed, numerous French and European film funding bodies exist to encourage transnational -and, by extension, multilingual-, filmmaking, such as the European Union initiative Eurimages, as well as the French CNC (Centre national du cinéma et de l'image animée) "Aide aux cinémas du monde" and coproduction support schemes. ${ }^{5}$

Yet despite this culturally diverse cinematic heritage, contemporary French multilingual films, are strikingly different from twentieth-century multilingual films. This is due not merely to the sheer increase in their quantity of multilingual dialogue, but to their opposing representations of the value of foreign languages. For example, in Charef's 1985 film Le Thé au harem d'Archimède, widely considered to have triggered the cinéma de banlieue movement (Abecassis, 2010, p. 34), the familial language of Arabic is actively rejected by the protagonist Madjid, who pretends not to understand when his mother speaks to him in her native tongue. Hargreaves and Kealhofer suggest that this renunciation of his multilingual heritage demonstrates "that Madjid's linguistic and cultural ties are clearly stronger with France", in stark contrast to those of his mother (Hargreaves and Kealhofer, 2010, p. 77). In many, if not all, beur and banlieue films of the 1980s and 1990s, foreign languages are the language of the home, not the public sphere, and a source of disconnect between migrant parental generations and their second-generation children, who attempt to shake off their parents' language in an attempt to integrate into French society (Johnston, 2010, p. 89).

This recurrent dynamic of language relations implies a linguistic hierarchy, with French presented as an asset imbued with political, colonial and cultural force and with marginalised languages shown to represent a hindrance, a liability or even a point of shame. Multilingualism is depicted as a cultural reality in these films, but rarely, if ever, as a source of power. Rather, languages other than French are portrayed as holding considerably less currency than French in public life. Invariably, French constitutes a "power language"; a prestigious code imbued with Western dominance and colonial history, and thus symbolic power. This recalls Sanaker's (2008) claims that "immediately after the end of the Second World War, English was the obvious means of expressing Anglo-American power... which did not prevent French, another language with a significant colonial heritage, to play the same imperialistic role" (p. 150). ${ }^{6}$ Likewise, Smith (2010) recognises the traditionally dominant role of the French language in its native cinema: "the French cinema, relatively industrially strong, is a good example of ... a local hegemony, in which resistance to the incursions of a globalized 
English goes hand in hand with the assertion of the importance of French as a national marker" (p. 40). Consistently, the non-contemporary films we have mentioned uphold the concept of a stratified linguistic hierarchy.

By contrast, contemporary French multilingual films, as shown by our case study Un prophète, constitute a marked departure from this dynamic of language relations, offering a new vision of what might be understood by the term "power language". In Johnston's (2010) words, the linguistic "hybridity" of French multilingual cinema can "be seen as leading towards a renegotiation of the French republican model to accept within its discursive (and, by extension, more broadly socio-cultural) limits, a 'French other' and the paradox inherent in this term" (p. 97).

\section{Un prophète}

With dialogue in French, Arabic and Corsican, multilingualism is a central element of Un prophète, whose characters constantly employ language as an important strategy in their struggle for dominance over one another. As Hoad explains in his 2010 Guardian article "A Prophet Shows Us a Multilingual Future for Cinema", "the film catches the dark side of language- its relationship to power; it can be a badge of belonging and is used to exclude as well". The film presents a mise en abyme of the broader cultural and racial tensions rife in contemporary France, a recurring characteristic of multilingual film, which Strand (2009) sees as an " "echo chamber' of society" (p. 269). Yet despite its broader cultural relevance, Un prophète's mise en scène is an insular one: the vast majority of the film takes place within the bleak confines of the Brécourt male prison, on the outskirts of Paris. While a considerable proportion of the inmates and staff are French, the prison is ruled and divided by two conflicting cultural gangs: the Arabs, who keep mostly to themselves, and the Corsicans, whose criminal network extends to a number of the prison's senior guards, and whose leader, César, effectively controls the prison from within. The prison is a rigid, brutal and ritualised space in which the lines between cultural groups are rarely, if ever, traversed.

Enter Malik, a nineteen-year-old Franco-Arab prisoner, who has been sentenced to six years of imprisonment at Brécourt for supposedly attacking a policeman in a banlieue riot (a crime he denies). Malik begins his internment at the bottom of the food chain, and is subjected to a vicious series of beatings, sexual propositions and to racial vilification. Yet the film's ultimate focus is not on Malik's victimisation in the prison, but on his evolution from social outcast to gang leader. As the plot progresses, it becomes apparent that Malik is not afraid to use violence to establish himself as a key player in the social landscape of Brécourt. Yet Malik's ascent of the prison's social ladder is effected not so much through his aptitude for brutality, but through his ability to learn, harness and manipulate multiple languages. According to Hoad in his aforementioned article, while "French... is the lingua franca in the prison... it is Malik's fluency in other languages that drives the plot, and his rise to power" (2010). In a subversion of traditional language 
relations, French functions as the linguistic common ground for all of the prison's inhabitants, yet it is Malik's fluency in Arabic and Corsican which allows him to negotiate himself a position of authority.

Malik arrives at the prison bilingual in French and Arabic, yet unaligned with any particular cultural identity or group. He does not attempt to make any friends upon his arrival, nor does he request to be lodged in the quarters traditionally inhabited by the Arab inmates. This renders him useful to the prison's wildly powerful Corsican gang, who recruit him as a pawn and a go-between in dealings with their Arab rivals. At the outset, Malik is kept simultaneously within the gang and on its periphery, as the members exclude him by speaking Corsican in his presence, rather than French. Yet using his newly-acquired literacy skills (he learns to read in the prison's school), Malik secretly teaches himself Corsican from a pocket dictionary. He thus adopts a unique linguistic perspective, becoming the only character in the film capable of understanding and communicating in the three languages of the prison. Language subsequently becomes a key tool in Malik's ascent to power, and he exploits his new-found trilingualism in order to eavesdrop on the Corsicans' secret conversations, to establish a broad criminal network across cultural boundaries and to penetrate both of the prison's dominant -and polarised- power centres.

At the heart of Malik's power play is his strategic use of code switching. A sociolinguistic concept, code switching refers to the act of shifting from one language (or language variation) to another, within a single linguistic exchange (Dwyer, 2005, p. 295). This process can take place in all manner of situations and for a variety of reasons; in Un prophète, code switching is pivotal as a manoeuvre employed in renegotiating hierarchical relationships. The film's events reflect Smith's (2010) view that

[t]here is more at stake in filmic employment of code switching than mere fidelity to a previously established external reality: that, in fact, the decision to employ multiple languages in film represents a strategy for critical assessment of linguistic and social hierarchies (pp. 37-38).

Through an adept use of code switching, Malik transforms his mastery of multiple languages into a means of exclusion, intimidation and manipulation, allowing him to gain control over his oppressors and eventually to overturn the power dynamic between himself and his tormentor, César.

One scene in particular revolves explicitly around code switching as power strategy. The scene takes place in one of the prison visiting rooms, where Malik is consulting with his friend Ryad, a former inmate of similarly Franco-Maghrebin descent. Both men have been employed by César to handle a drug smuggling job for the Corsicans, using their own men. The arrangement has fallen through for a variety of reasons, but the Corsicans blame Malik and Ryad. The centrality of language in 
this scene is clear, as Malik manages the precarious situation through a juggling of both French and Arabic.

The scene begins with a discussion between Malik and Ryad in which French, not Arabic, is their language of choice. Ryad attempts to convince Malik of the seriousness of their situation: their employees are threatening to rebel against the Corsicans. ${ }^{7}$

Ryad [French]: Are you listening? It's bad. Our guys are good for drugs. Not for other stuff.

Malik [French]: You were the one who wanted to do it. What are we going to do now?

Ryad [French]: I can't force them. When the Corsicans took out their guns they ran off. Like devils. That bastard Vettori treats us like shit. There was a fight on the way to Paris. Now Khalid wants to kill him.

Malik [French]: You'll have to fix it. Find some other guys.

Ryad [French]: Now? Under contract?

Malik [French]: Who cares?

Their conversation is brought to an abrupt halt as César and his sidekick Vettori enter; César accuses Malik and insults Ryad.

César [French]: OK, it stops here. You've wasted my time and money with your group of idiots; just look at him! [points to Ryad] Ryad [French]: Be careful what you say.

When Ryad defends himself, Vettori threatens him with physical violence.

Vettori [French]: I will deliver you from your misery! [Seizes Ryad]

Malik [French]: Hands off! Stop!

To defuse the situation, Malik draws on his multilingualism. Switching to Arabic, as if to suggest to the Corsicans that Arabic is indeed his and Ryad's preferred code (a reasonable suggestion considering their mutual backgrounds), he placates his friend, promising him that they will not agree to submit to the Corsicans.

Malik [Arabic]: Ssh! We'll do it our own way.

César becomes immediately suspicious:

César [French]: What are you saying?

This is a key moment: the first time in the film that César finds himself in a position of linguistic ignorance and therefore vulnerability. Malik lies:

Malik [French]: I'm trying to make him understand. May I?

It is with these two phrases that the (unrequested) interpreting begins. While he could reasonably continue to protest at Malik's use of Arabic, César cedes the disciplining over to him. César is clearly uncomfortable at finding himself in a position of incomprehension and subsequently a lack of control, yet is seemingly convinced by Malik's masquerade. 
Malik turns back to Ryad, and switches back to Arabic. Before their very eyes, he promises Ryad that they will kill the Corsicans.

Malik [Arabic]: Listen. We'll kill them. Promise. We'll kill them, but they can't know how.

Next, warning Ryad, Malik underscores his masquerade with a display of physical violence. Ryad is so taken aback by Malik's words that he even forgets to respond in Arabic, reverting automatically back to French; Malik is effectively acting alone by this stage.

Malik [Arabic]: I'm going to hit you. Lower your head.

Ryad [French]: What?

Malik [Arabic]: I'll hit you and you lower your head. [Strikes Ryad]

Switching back to French, he explains the blow to the Corsicans:

Malik [French]: It's ok, he gets it now. Shall we get on? [The Corsicans exit]

Malik is thus able to exploit his fluency in Arabic as well as French to placate both sides of the conflict in opposing ways.

Code switching is clearly instrumental here. Nonetheless, it is important to acknowledge that code switching does not function alone in the scene. Malik's ability to juggle both César and Ryad's agendas relies heavily on the pre-existing ritual of interpreting, or the translation pact.

\section{Un prophète and the treacherous interpreter}

The practise of interpreting is a ritualised one, which necessarily involves a measure of vulnerability and trust on the part of the subject for whom the interpreter is translating. In order for interpreting to function as a just and accurate means of linguistic and communicative transfer, the interpreter must abide by the rules of the interpreting ritual; that is, by correctly translating spoken material from one language to another, without perverting or adjusting its meaning. The interpreter must provide a faithful translation, and the translation subject must accept the faithfulness of the translation being provided, without, of course, being able to confirm its validity (assuming that the subject is completely ignorant of the language of translation, as César is of Arabic). Hence, the scenario involves a verbal pact and a relationship of trust entered into necessarily and, as a general rule, naturally.

In interpreting, there is by definition an imbalance in the linguistic capacities of the individuals involved. Namely, the interpreter possesses a multitude of linguistic competencies, and has the resource of at least two languages at his/her disposal. By contrast, the subject relying on the interpreter does not possess the same level of linguistic understanding and is, therefore, at the interpreter's mercy, unable to understand the content of a linguistic exchange without the latter's guidance. In other words, the 
translation subject occupies a position of vulnerability. If the interpreter lies, s/he will not know it. This affords the interpreter great potential for power, which Delabastita (2005) underlines: "translators make enormous scores for power and responsibility, if one takes into account both their control over flows of information... and the sheer linguistic and cultural gap to be negotiated" (p. 21).

It has been firmly established in translation studies that an interpreter in any situation is, by definition, assumed to possess this linguistic power, and the translation subject will, by definition, be subject to this linguistic vulnerability. As a result, this imbalanced relationship poses an inherent risk:

Incomprehension is a matter of the incommensurability of the languages and cultures involved (knowledge, value and belief systems), but it can be seriously aggravated in cases where the cultural constituencies meeting through translation have radically opposed interests and agendas (Delabastita, 2005, p, 19).

The potential for an interpreter to hijack a translation sequence and to exploit the subject's trust, as occurs in Un prophète, appears to be immense. However, this rich research area remains relatively unexplored.

In aforementioned films like Entre les murs and Le Mépris, the exclusion of subtitles in interpreting sequences demonstrates first-hand to the audience the extent to which the translation subject's understanding is in the interpreter's hands, and the measure of trust, and subsequently of vulnerability, involved in participating in the ritual of interpreting. Taking this concept even further, Un prophète demonstrates how this trust can be exploited by an interpreter for his/her own benefit. Unlike, for example, the committee meeting scene in Entre les murs, in Un prophète, all dialogue is subtitled throughout the interpreting scene, in order for the audience to witness and comprehend the crucial moment of Malik's manipulation of the Corsicans. The audience, whether they understand Arabic or not, can therefore see how the treacherous interpreter perverts the content to be translated for his/her own means, using the ritual of translation as a masquerade in order to dupe the individual relying on the translation in his/her very presence. Exploitation of Malik and Ryad's fluency in (and César and Vettori's ignorance of) Arabic, paired with the ruse of playing the interpreter and the violent discipliner, is the key to Malik's ability to control the situation and satisfy the conflicting agendas of the two groups, while simultaneously protecting his own position as the cultural and linguistic bridge between them.

The success of Malik's treacherous interpreting is heavily dependent on an exploitation of the translation pact. However, this pact is not the only supporting framework which legitimises Malik's treachery. The ruse also relies on the support of physical violence. As previously mentioned, in order to convince César that he is indeed disciplining Ryad on the former's behalf, towards the end of the sequence, Malik strikes Ryad in the face. He then justifies this move in French as being one of punishment on César's behalf. Extending the masquerade from a 
linguistic to a physical one deeply legitimises Malik's claim. Indeed, the blow seems to be the detail which ultimately satisfies César, who subsequently leaves the room without pursuing his criticism and punishment of Malik and Ryad any further. If César was reluctant to accept Malik's translation of his Arabic-language discourse with Ryad in the earlier stages of the sequence, the introduction of physical violence appears to convince him.

Indeed, César frequently uses violence himself to communicate with his subjugates, to punish them and to reaffirm his position of authority. Constantly oscillating between French and Corsican in order to conspire and exclude, César also often deploys violence as another form of communicative and persuasive code. Speaking from a speech act theory perspective, Pratt (2009) explores this language-violence dyad "whereby language is required for violence to have meaning or an alibi, while violence gives a speech act its force" (p. 1529). In striking Ryad, Malik is behaving in the way César would to discipline Ryad, thus convincing César that what he is hearing indeed corresponds to what he is seeing. Malik's manoeuvre reflects Pratt's (2009) claim that "violence calls forth language to articulate or assign it meaning" (p. 1529). In a very literal way, at this moment, actions speak louder than words.

It is thus quite clear that Malik possesses a form of power over his fellow prisoners, in this scene in particular and more broadly in the film. What the ability to manipulate and control means for Malik as an individual is nonetheless problematic. Malik's ascent of the social ladder in the prison results, paradoxically yet inevitably, in his descent into the world of crime. As Malik gains autonomy and independence from his oppressors, he becomes more violent, more dangerous and more morally ambiguous. It could even be said that Malik plays into xenophobic mainstream French stereotypes of the disenfranchised Franco-Arab figure. Audiard's film is certainly not concerned with portraying Malik as a simple hero. What Malik's power permits and encourages him to do is an important consideration in any moral analysis of Un prophète as sociocultural comment on France and its migrant populations. The aim of this article, however, is not to judge the quality of Malik's character as he evolves into the crime boss he ultimately becomes. Instead, it is to examine how such an impossibly ostracised and vulnerable individual can find the means to harness power. Our ultimate concern is to highlight the opportunities afforded to this disenfranchised individual by a seemingly innocuous resource: language. Malik is no hero, nor does this article seek to present him as one. He is, nonetheless, a powerful character, due to his mastery of language. It is, then, the acquisition of power, rather than its moral implications, which we seek to explore.

\section{Conclusion}

Contemporary multilingual French films do not present a utopic or naïve view of contemporary cultural relations, nor one which does not take into account the lingering shadow of colonialism in French society. Rather, 
they represent a tentative step in the direction of a new discourse in French cinema which envisions the possibility of marginalised peoples as capable of negotiating themselves a position of empowerment, with, and indeed through, use of similarly marginalised languages. French, of course, has its value in Un prophète, as the prison's lingua franca. Yet Malik's linguistic power lies not in his fluency in French, but in his knowledge of Arabic and Corsican. In the specific context of the film's setting, both these languages present potential for power, despite being derived from cultures which have been either officially colonised, or at least historically dominated, by the French. In the specific domain of the prison, the dual exploitation of these alternative codes is Malik's key to negotiating himself a unique position of authority. Thus the film compels us to imagine a new definition of the "power language" as a concept which extends beyond the dominance of colonial or typically culturally prestigious languages such as French to encompass the potential power of even the most peripheral of codes.

Un prophète is one of an ever-expanding number of contemporary French films which foreground and valorise the complexity and richness of multilingual interaction. Painting a brutal portrait of the underbelly of French society, the film places multilingualism at its core, demonstrating the extent to which competence in multiple languages and translation practices can be harnessed as a power mechanism and a means of manipulation. Un prophète's characters live in a world where fluency in French is neither sufficient to make it in underworld business, nor indeed to survive. Indeed, in such a codified and diverse environment, multilingual figures possess a distinct and literal advantage over their monolingual peers. In its depiction of strategic code switching, the film highlights the much-neglected importance of multilingualism, the complex role of the interpreter and the potential for symbolic power inherent not only in the use of French or other dominant Western tongues, but in the many minority languages which comprise the social fabric of an increasingly diverse, fragmented and multilingual French society.

\section{Bibliography}

Abecassis, M. (2010). The voice of pre-war French cinema: From polyphony towards plurilingualism. In V. Berger \& M. Komori (Eds.), Polyglot cinema: Migration and transcultural narration in France, Italy, Portugal and Spain (pp. 33-48). Vienna: LIT.

Carion, C. (2005). Joyeux Noël. Le Journal de Montréal, 3 December.

Delabastita, D., \& Grutman, R. (2005). Fictional representations of multilingualism and translation: An introduction. Linguistica Antverpiensia New Series, 4, 1134.

Dwyer, T. (2005). Universally speaking: Lost in Translation and polyglot cinema. Linguistica Antverpiensia New Series, 4, 295-310.

Gramling, D. (2010). On the other side of monolingualism: Fatih Akin's linguistic turn(s). German Quarterly, 83(3), 353-373. 
Hargreaves, A., \& Kealhofer, L. (2010). Back to the future?: Language use in films by second-generation North Africans in France. In V. Berger \& M. Komori (Eds.), Polyglot cinema: Migration and transcultural narration in France, Italy, Portugal and Spain (pp. 75-88). Vienna: LIT.

Hoad, P. (2010). A Prophet shows us a multilingual future for cinema. The Guardian, 28 January. (Accessible at: http://www.guardian.co.uk/film/filmblog/2010/ jan/28/jacques-audiard-a-prophet), last accessed 28 March 2013.

Johnston, C. (2010). Intergenerational verbal conflicts, plurilingualism and Banlieue cinema. In V. Berger \& M. Komori (Eds.), Polyglot cinema: Migration and transcultural narration in France, Italy, Portugal and Spain (pp. 89-98). Vienna: LIT.

O'Sullivan, C. (2008). Multilingualism at the multiplex: A new audience for screen translation? Linguistica Antverpiensia New Series, 6, 81-95.

Pratt, M-L. (2009). Harm's way: Language and the contemporary arts of war. The Modern Language Association of America, 124(5), 1516-1531.

Sanaker, J-K. (2008). Les Indoublables: Pour une éthique de la représentation langagière au cinéma. Glottopol, 12, 147-160.

Smith, A. (2010). All quiet on the filmic front?: Codeswitching and the representation of multilingual Europe in La Grande Illusion (Jean Renoir, 1937) and Joyeux Noël (Christian Carion, 2005). Journal of Romance Studies, 1(2), 37-52.

Smith, A. (2012). Crossing the linguistic threshold: Language, hospitality and linguistic exchange in Philippe Lioret's Welcome and Rachid Bouchareb's London River. Studies in French Cinema, 13(1), 75-90.

Strand, D. (2009). Etre et parler: Being and speaking French in Abdellatif Kechiche's L'Esquive (2004) and Laurent Cantet's Entre les murs (2008). Studies in French Cinema, 9(3), 259-272.

Wahl, C. (2005). Discovering a genre: The polyglot film. Cinemascope, 1, 1-8.

\section{Filmography}

Attal, A. (Producer), Maïwenn (Director). 2011. Polisse [Motion picture]. France: Les Productions du Trésor.Languages: Arabic, French, Italian, Romanian.

Balsan, H. (Producer), Ferroukhi, I. (Director). 2004. Le Grand Voyage (The Great Journey) [Motion picture]. France: Ognon Pictures. Languages: Arabic, Bulgarian, English, French, Italian, Serbo-Croatian, Turkish.

de Beauregard, G., Levine, J. E. and Ponti, C. (Producers), Godard, J. (Director). 1963. Le Mépris (Contempt) [Motion picture]. France: Les Films Concordia. Languages: English, French, German, Italian.

Bender, L. (Producer), Tarantino, Q. (Director). 2009. Inglourious Basterds [Motion picture]. USA: Universal Pictures. Languages: English, French, German.

Benjo, C. and Scotta, C. (Producers), Cantet, L. (Director). 2008. Entre les murs (The Class) [Motion picture]. France: Haut et Court. Languages: Berber, French, Spanish.

Boeffard, P., Faivre, B. and Rossignon, C. (Producers), Carion, C. (Director). 2009. L'Affaire Farewell (Farewell) [Motion picture]. France: Nord-Ouest Productions. Languages: English, French, Russian. 
Bouchareb, R., de Braconier, M., Bréhat, J. and Faivre, B. (Producers), Bouchareb, R. (Director). 2009. London River [Motion picture]. France: 3B Productions. Languages: Arabic, English, French.

Cassinelli, M. and Dedet, A. (Producers), Audiard, J. (Director). 2009. Un prophète (A Prophet) [Motion picture]. France: Why Not Productions. Languages: Arabic, Corsican, French.

Caucheteux, P. (Producer), Audiard, J. (Director). 2005. De battre mon coeur s'est arrêté (The Beat That My Heart Skipped) [Motion picture]. France: Why Not Productions. Languages: English, French, Mandarin, Russian, Vietnamese.

Clifford, F. (Producer), Duvivier, J. (Director). 1932. Allô Berlin ? Ici Paris ! (Here's Berlin) [Motion picture]. France, Germany: Société des Films Sonores Tobis. Languages: French, German.

Coppola, S. and Katz, R. (Producers), Coppola, S. (Director). 2003. Lost in Translation [Motion picture]. USA: Focus Features. Languages: English, Japanese.

Gatlif, T. and Rubio, M. (Producers), Gatlif, T. (Director). 2004. Exils (Exiles) [Motion picture]. France: Princes Films. Languages: Arabic, French, Romany, Spanish.

Gavras, C. and Ray-Gavras, M. (Producers), Charef, M. (Director). 1985. Le Thé au harem d'Archimède (Tea in the Harem [of Archimedes]) [Motion picture]. France: Centre national de la cinématographie. Languages: Arabic, French.

Golin, S., González Iñárritu, A. and Kilik, J. (Producers) González Iñárritu, A. (Director). 2006. Babel [Motion picture]. USA: Paramount Pictures. Languages: Arabic, Berber, English, French, Japanese, Japanese Sign Language, Russian, Spanish.

Justice, M. and Levy, B. (Producers), Klapisch, C. (Director). 2005. Les Poupées russes (Russian Dolls) [Motion picture]. France: Lunar Films. Languages: Castilian Spanish, English, French, Italian, Russian.

Karmitz, M. (Producer), Haneke, M. (Director). 2001. Code inconnu: récits incomplets de divers voyages (Code Unknown: Incomplete Tales of Several Journeys) [Motion picture]. France: Bavaria Film. Languages: Arabic, English, French, French Sign Language, German, Malinka, Romanian.

Levy, B. (Producer), Klapisch, C. (Director). 2002. L'Auberge Espagnole (The Spanish Apartment) [Motion picture]. France: Bac Films. Languages: Castilian Spanish, Catalan, Danish, English, French, German, Italian.

Pinkovitch, A. and Rollmer, F. (Producers), Renoir, J. (Director). 1937. La Grande Illusion (Grand Illusion) [Motion picture]. France: Réalisation d'art cinématographique. Languages: English, French, German, Russian.

Rossignon, C. (Producer), Lioret, P. (Director). 2009. Welcome [Motion picture]. France: Nord-Ouest Productions. Languages: English, French, Kurdish, Turkish.

Rossignon, C. and Herrmann, B. (Producers), Carion, C. (Director). 2005. Joyeux Noël (Merry Christmas) [Motion picture]. France: Nord-Ouest Productions. Languages: English, French, German, Latin. 
1 Analyses of multilingual film frequently employ variations in terminology; Wahl refers to "polyglot" cinema, while others use terms such as plurilingual, polylingual or heterolingual. While each has its own nuances, this article will simply employ the label "multilingual" as the most straightforward and universally comprehensible term to indicate the use of multiple languages in film.

2 Data gathered from the author's doctoral research. King, G. Multilingualism and Power in Contemporary French Cinema. The University of Melbourne/Paris 3: Sorbonne Nouvelle. Forthcoming in 2015.

3 Dwyer emphasises the importance of the recurrent role of the figure of the translator/interpreter in multilingual film, as a literal, diegetic mouthpiece for cultural and linguistic transfer.

4 Klapisch's 2005 sequel, Les Poupées russes, added Russian to this linguistic melting pot.

5 Eurimages "European Cinema Support Fund": http://www.coe.int/eurimages/. CNC international funding schemes: http://cnc.fr/web/fr/international/.

6 French-language original: «Immédiatement après la fin de la Deuxième guerre mondiale, l'anglais est l'expression évidente du pouvoir anglo-américain...ce qui n'empêche pas le français, autre langue ayant un lourd héritage colonial, de jouer le même rôle impérialiste ». Author's own translation.

7 All English-language translations of film dialogue are taken from the Australian DVD release of the film in question. 